\title{
Inequality confirmed: institutional exclusion in the interaction between job-centre advisors and unemployed young people
}

\author{
Ulla Rantakeisu* \\ Department of Social and Psychological Studies: Social Work \\ Karlstad University \\ Email: ulla.rantakeisu@kau.se \\ *corresponding author
}

\section{Kirsti Kuusela}

Department of Social and Psychological Studies: Social Work

Karlstad University

Email: kirsti.kuusela@kau.se

\section{Lis-Bodil Karlsson}

Department of Social and Psychological Studies: Social Work

Karlstad University

Email: lis-bodil.karlsson@kau.se

\begin{abstract}
Since the 1990s, the pressures on the unemployed have intensified in Sweden owing to increasing demands on individuals to be employable. This article centres on unemployed youths' experiences of their visits to the public employment services in four Swedish municipalities and how these experiences can be understood against the background of the intersection of social class and gender. A total of 18 unemployed youths were interviewed and their reasoning was compared with their respective employment-agency officers. The analysis shows that the employment agency gives priority to young working-class men over young working-class women and to middleclass youths over working-class youths, respectively. Young working-class women's wish to combine employment with caregiving is seen as an encumbrance by the employment agency and these women expressed the harshest criticism against the employment agency. When the advisors meet youths who do not correspond with the current expectations and ideals of the labour market, they risk taking part in an institutional process of exclusion of these youngsters.
\end{abstract}

Keywords: Unemployment, employment agency, job centre, emotions, gender, social class, exclusion 


\section{Introduction}

Starting work for the first time or re-starting after a period of unemployment can be a complicated process involving more than merely individual aspects. In Sweden, the Public Employment Service has a central role in labour-market politics. It is an important actor because of its double role of providing service to job-seekers and employers, on the one hand, and identifying unemployed people who abuse unemployment benefits, on the other (Calmfors, Forslund, \& Hemström, 2002). In the 1990s and 2000s, the demands on the unemployed to seek and find work have become stricter, which is similar to the development in other European states (Heikkilä, 1999). The Public Employment Service's efforts have gradually shifted from supporting and controlling to supporting by controlling (Walter, 2011). Current labour-market policy is implemented through increased monitoring. The officials' authority to assess and question an unemployed person's steps and actions in the labour market makes for an asymmetrical power relationship, meaning that the officer has the interpretative prerogative of defining a situation.

Studies of street-level bureaucrats (Lipsky, 1980), that is, officials in direct contact with citizens, show that they have great opportunities to influence the interaction with citizens because of their chance to convey daily messages on how individuals should act as clients, job-seekers, and so on (Hydén, 1996; Romppainen, Jähi, Saloniemi, \& Virtanen, 2010; Skogens, 2011). Norms and values are established of what is desirable, that is, the experiences and knowledge routinely defined as important and what is less important (Hasenfeld, 2000). Research with a citizen perspective also points to different experiences of contacts with the welfare institutions' street-level bureaucrats (McArthur, Thomson, \& Winkworth, 2013). The present study focuses on a determining aspect of the process of (re-) entering employment, namely, on what takes place when a job-centre advisor meets a young unemployed person in pursuit of a job. The aim of the study is to investigate the interaction between advisors and the young unemployed with an emphasis on the young people's experiences and how they cope emotionally and to consider whether different patterns of experience can be generated from the unemployed youths' own living conditions.

Knowledge of interaction at the employment agency is urgently needed to understand the changes on the labour market in last decades involving a greater emphasis on the individual as a saleable labour-market commodity (Garsten, \& Jacobsson, 2004). People are expected to be mobile, adaptable, and adjustable, where the responsibility for being employable lies with the individual (Salomonsson, 2005). Employees are trained to act as entrepreneurs, to be flexible, to embrace life-long learning, and to learn different managerial methods for job interviews (Fogde, 2010; Sharone, 2007).

Even if the visits to the employment agency take place on the terms of the organization, the basic values that each individual has also colour the visits (Tilly, 1998). Different life circumstances are important for how the prevailing labour-market norms are accepted, not least for the effects of welfare political reforms. A meta-analysis of evaluation studies shows that participants' sex, age, and ethnicity are often equally important, and sometimes even more so, than programme design in determining the success of welfare-to-work programmes (Ashworth, Cebulla, Greenberg, \& Walker, 2004): the fewer the non-whites, the women or the people under 30 there were, the greater the success of the programmes. Sharone's (2007) study of unemployed well- 
educated, white-collar workers indicates that individual competition, an emphasis on entrepreneurship, and marketing themselves were considered obvious aspects of their job-seeking. Fogde (2010) shows that academically educated students take an individual attitude to career advice. Another researcher has argued that the ideal image of employees in manuals written for the unemployed are masculinely coded, which can have consequences for women's career opportunities (Andersson, 2003). Furthermore, according to Persson Thunkvist (2003), unemployed working-class youths display a resistance to an approach of learning to be competent job applicants that is in line with the ideals of the time and of the middle classes, that is, with an emphasis on individual performance and competition.

Labour-market norms and inclusion as well as exclusionary mechanisms in respect of sex, class, or age, for example, have been the objects of study. Comparative studies of women and men and between social classes with regard to social life conditions are, however, more scarce. This article aims to redress this lack of attention in the literature.

\section{Exclusion, multiple inequalities, and emotions}

Like other Western European welfare states, Sweden has developed a tighter control of the unemployed, partly explained by the economic crisis in the 1990s. In contrast to other Western European countries, Sweden had long enjoyed low unemployment and high employment rates, but in the 1990s the unemployment rates doubled. The concept of social exclusion is used to denote a situation in which people are unable to participate in society, especially the labour market (Rodgers, Gore, \& Figueiredo, 1995). People can experience social exclusion particularly in contacts with welfare institutions that deal with unemployment and poverty, according to Kronauer (1998). The lower the extent to which employment and social services can help people out of unemployment and poverty, the higher the extent to which these organizations contribute to reproducing what Kronauer calls an institutional exclusion. The concept of institutional exclusion enables us to understand the processes of inequality that are reproduced at the studied job centres in a welfare state like Sweden. Despite efforts made towards inclusion by increased resources intended to improve labour-market links, the consequences might be the opposite. In our article we consider institutional exclusion as a process through which the interaction between the actors concerned reduces individuals' active possibilities for manoeuvring in the employment market and thus affects young people's life conditions. Our focus is if and how certain groups are dis-benefitted by their interaction with employment agencies.

We study a set of unequal social relations - the intersection of the multiple inequalities of class and gender - considered as autonomous social structures (cf. Walby, Armstrong, \& Strid, 2012). We analyse this interaction in the interpretative frame of life-mode theory. Life-mode theories are connected to the material conditions of class analysis, but they also emphasize the core values of ideologies or cognitive configurations (Højrup, 1989; Jakobsen \& Karlsson, 1993; Jakobsen, 1999; 2005): people who live different life modes tend to have various everyday norms of what constitutes a good life and of what is possible to do in order to attain the good life aspired for (Jakobsen \& Karlsson, 1993). Everyday life consists of work and love. The means of existence are produced through what Jakobsen $(1999 ; 2005)$ calls the forms of 
work, while the forms of love produce life itself, which in turn is the precondition of human existence in itself and regulated by strong norms (cf. also Jónaisdóttir, 1994). The forms of work focused on in our study are the traditional wage-earning jobs and the career-oriented jobs. These forms of work are related to social class structures, such as the working and middle class. Referring only to two social classes is admittedly a simplification in this context but it helps analytically to clarify how social class entails differences in power and lead to inequality (Skeggs, 1997). Two dominant forms of love can be identified, which in turn are related to the gender structure of society: the male empowering love and the female confirming love. These structures can aid our understanding of the norms and values that the young unemployed people express in their contacts with the employment agency.

Norms and values can be related to emotions. Emotions in the form of signals of feelings show how we assess situations (Hochschild, 1990). Together with rational components emotions play an essential role in every social interaction (Dahlgren, \& Starrin, 2004), not least in the contact with street-level bureaucrats (Svensson, Karlsson, Alexandersson, \& Nordqvist, 2003). Social relations are created in the process of interplay between individuals, but are felt within the individual. Experiences are narratives about what the contact feels like, for example, unemployed young people's experiences of contacts with the employment agency. Knowing how the young people emotionally handle their norms and values in their contacts with the employment agency helps us to understand the underlying mechanisms.

\section{Method}

We chose a qualitative interview design to collect contextual data. Initially, four public employment-agency offices (hereafter referred to as 'job centres') were selected in different mid-Sweden urban and rural municipalities, with the intention of representing different demographic and socioeconomic character. The manager of these job centres selected the advisors who had at least five years of experience. The nine interviewed advisors were all women. These advisors in their turn asked unemployed young people to participate; this was based on purposive sampling and it was a way of maximizing social differences (Silverman, 2006) such as age and sex, how long they had been unemployed, and which upper secondary programmes they had attended. When we considered social class in our study, we used two broad and still common categories in research (Skeggs, 1997). The idea was to recruit respondents from academic as well as vocational programmes on the assumption that young people's choice of upper secondary educational programmes is both class- and gender-specific (Hagquist, 2000). We employed the categories of working class and middle class in relation to the young respondents' background in respect of education, work experience, and parents' occupations, where education was the most influential factor in the categorization.

One of the authors (U.R.) interviewed 18 young unemployed persons in the 21-24 age range, whose periods of unemployment varied but were never less than ten weeks. Eight respondents were women and ten were men. These interviews were followed by interviews of their advisors. The data were collected with the help of an interview guide consisting of open thematic questions. All interviews were recorded and transcribed verbatim. 
To determine whether class had an impact on the respondents' experience of the job centre, unemployed men with different social backgrounds were compared and likewise unemployed women with different backgrounds. When differences between the sexes were found, we compared unemployed men and women with similar social-class backgrounds. The concepts of forms of work and forms of love were the starting-points of the analysis, in line with the orienting concepts as suggested by Layder (1998). We analysed the relations between the advisors and youths on the basis of the different perceptions that can be perceived in a contact depending on the various positions that social actors take in a relation.

We coded the interviews with the help of a combination of what Kvale and Brinkmann (2009) denote 'meaning concentration' and 'meaning categorization', that is, by extrapolating the essential information that can be grouped into common categories. The analysis was mainly analytically inductive (Boolsen, 2007), based on an interaction between theoretical concepts and the categorization of the transcript material.

\section{Results}

This section presents the experiences of the young respondents and the advisors. We describe the unemployed working-class youths' experience, which can be understood in the light of the norms of traditional wageemployment. There are also gender-specific experiences which must be included in an analysis of the norms of gender structures. Finally, we present the experiences of middle-class youths on the basis of the valuations of career-oriented jobs.

\section{High expectations and dependency}

The working-class youths' expectations on the job centres are high. The expectations can be interpreted against the background that these young people lack a social network to help them out of unemployment and that their economic situation demands an immediate solution. They expect the advisor to show them a way out of unemployment if they cooperate. Their expectations are based on the norms and values informing employees of what is expected of them, namely, that the employer is responsible for how the labour force is used and what the employee is expected to do. Working-class youths have the same expectations on the employment authority. They expect the official to tell them how and what to do, and then they will do it and immediately get a job as a result. These expectations combined with the increasing need for help over time pave the way for a growing distance to the job centre.

The job-centre advisors on their part report that these young unemployed people have an exaggerated faith in the duty of the employment agency. Their demands for a quick solution and requests for hands-on cooperation to secure a job become, despite the generality of the attitude, individualized by the official: 'I think [the job centre] can be the scapegoat for their own shortcomings also, because there I can hear: "I have not got any help from you".' 
The youths' expectations are thus interpreted by the professionals as individual expressions of personal failure or a way of escaping personal responsibility. The norms of working-class youths are in fact in opposition to the employment agency's basic principle that the unemployed are responsible for finding a solution themselves - provided that the job-seeking takes place on the agency's terms.

\section{Oppositional defiance and rejection of norms}

The working-class youths' expectations of hands-on help tend to be frustrated. Misunderstandings, and at worst conflicts, can result and be manifested emotionally in the form of contempt, anger, or sarcasm. Some adopt an oppositional, defiant position, even though they do not always express their feelings to the advisor. On the contrary, there is a high degree of self-control it is important to restrain feelings in the face of the authority's judgement. On the one hand, they try to present correct behaviours, but, on the other, they describe through language use and expressions of feelings how they reject the officials' norms when they encounter them. The young people also experience a rejection of their norms. It seems that they swing between keeping within the bounds of agency norms by what we see as flexible compliance and defying and rejecting the advisors. This vacillation relates to their limited possibilities to influence the agency's norms and rules through negotiation.

An expression of the young people's defiance is to protest against various situations in their visits that are ungraspable, not to mention painful. This kind of rejection is described in detail in the interviews. A young man describes what happened when he failed to tick a box in the form: 'But then you miss a detail, you see! And the well-educated person working there can't figure that out. Is it possible that he might just imagine that I made a mistake? No way! So I must go back and make a supplementary report.' The frustration involves being at a social disadvantage and experiencing one's own shortcomings. They recount situations in which they feel misunderstood and even offended. When one of the men talks about an unemployment scheme where he was supposed to learn how to highlight his unique competence [as a welder] in writing with a great deal of swearing, it is an emotional way of dealing with being categorized as deficient. From a working-class position it is not fair to say that he has a unique competence to offer; rather, it is more accurate to say that he offers his working time. To him these demands are incomprehensible. When one of the young women describes the advisor's focus on work as an interest, she exclaims sarcastically, 'Interest? My foot! You need money and I would take any job.' From her working-class perspective the notion of a job as an interest is foreign to her and indeed stressful. Interests are pursued in leisure time.

The working-class youths want to cooperate with the job-centre advisors by forming an alliance based on understanding and getting assistance with what, how, and when. When this is not achieved, the young people demonstrate an emotional rejection of the advisors, responding to what they regard as incomprehensible demands. The visits to the job centre are crucial to the working-class youths. They rely to a great extent on the employment agency to get a job but at the same time the norms of the system are not adjusted to their culture. 


\section{He can negotiate while she is expected to take any job}

Compared with young working-class women, their male counterparts have a greater chance of manoeuvring their way out of meeting the job-centre requirement to apply for certain jobs, for instance, by saying, 'Of course, I'll apply for the jobs I want'. Unlike a woman, a man who has to apply for a notified vacancy according to the rules is to a greater extent allowed to influence the decision. The advisors give the young men certain possibilities for negotiation and offer different options; the men themselves can partly decide if they apply and what jobs they apply for. Working-class women are not given the same options. The young women's ifs are decided when they register as job-seekers. The same is true of what jobs they must apply for. The advisors think that the young women have a much too limited job-seeking profile because the women tend to consider their social situation of having a husband or boyfriend and starting a family etc. The young women take their partners' interests into account, for instance, their wish to stay in a place because they have a job there. This is perceived as an individual choice and from a labour-market perspective it is the wrong priority: 'And then [the advisor] begins immediately [saying that] there is something all the time that you put a stop to. Yes, but then if she had been in my shoes she would have known what I mean. Also. Yes, here at least l've [a boyfriend].'

The interviews with the advisors indicate that women in general are in fact expected to find a job themselves: 'Women, they are more autonomous.' An advisor puts it like this: 'In terms of gender, the guys take more of our resources, of my time. The girls have more drive.' The advisors also link the young women's own activity to the fact that labour-market training is offered to men to a greater extent (cf. also Lodenius, 2005): 'I can only say generally that there aren't as many training projects to offer the women. But many of the women do well anyway. I imagine that some perhaps work extra in social and health care.'

The employment agency does not treat the young unemployed working-class men as harshly as they do the working-class women when it comes to if they apply for a job and what jobs they apply for. To understand the differing experiences of the job centres between these men and women, the analytical concept of form of love is essential (Jakobsen, 2005). Young working-class men's and women's conception of work is typically that it is a means of reaching other goals beyond employment. The conception is a consequence of their position as working class. But their respective gender positions also generate different social norms of how men and women should behave. For the young working-class men the future employment must not infringe on their leisure time. When asked what they think about combining employment with family, they jokingly say that they have not given it much thought. To them, there is no conflict between work and family, something that other studies confirm (Kennerberg, 2007; Kugelberg, 2004). The young men's job-seeking pattern has no link to possible obligations in a partner relationship or caring for others.

When the young women seek jobs, on the other hand, they consider their current and potential future family formation. This means that there is a clash for the women between the demands of the employment agency, which represent labour-market norms, and the demands of the family sphere. The interviews show that when being both working class and a woman, flexibility manifests differently depending on if the woman is single or not, as one 
woman emphatically remarked: 'I will stay here now; this is where my boyfriend is.' If the woman is single, then she is geographically mobile. She can take a job somewhere else if there is no man to consider. However, if there is a boyfriend, his interests are protected and she stays where he wants to be as a result of an unequal distribution of power in love relationships. The advisors commend the former choice while they criticize the latter. However, with the latter women can be required to show job flexibility - meaning that they are expected by the agency to take any job. What she does in the labour market is thus conditioned by the needs of her nearest and dearest irrespective of marital status. In the next section we discuss what the visits to the job centre mean to young working-class men and women and their respective emotional manifestations.

\section{Attention and pity - invisibility and blame}

The interviews show that the working-class men are primarily successful in eliciting the help they want, or as one advisor puts it: 'You look more to who are [full-time] unemployed. Even if the women are that when they don't work full-time or the hours they want to, that's what it is, sort of. In some way the situation gets solved [for them] temporarily, you know.'

The young working-class men also manage partly to leave the responsibility for the job- seeking to the advisors, which also means that it seems as if it is the duty of the agency to solve the situation, or as one man puts it: 'Often I say to her [the advisor] that she has to fix something so she can have control. And then I sit there talking for five minutes.'

Although the young men can do manual work, they are rather ineffectual when it comes to applying for a job. The advisors show interest in them as cases and they get attention. The attention entails a sense of being someone, thus confirming and securing the relationship. The young working-class women, however, are expected to find their jobs on their own. In other words, they have greater challenges when it comes to adapting to the prevailing conditions of the labour market. The obligation to take any unqualified job is a result of women taking responsibility in the labour market as well as in the area of reproduction. This is an underlying issue that creates conflicts both in the young women's and in the advisors' accounts of their contact visits. As an advisor says: 'Then I can get a little irritated.' The working-class women's goals in relation to their loved ones are not accepted by the employment agency.

The advisors also describe conflicts in relation to job-seeking men and women in different ways: If and when conflicts arise in relation to men, it is because a point has been reached where the advisors can no longer negotiate between the interests of the agency, their job satisfaction, and the young men's requests. This is when advisors express that they themselves become 'a bit bitchy' in their interactions with the young men, or 'but I'm so mean then so I won't let them go.' In such situations the advisors attribute negative qualities to themselves and the institution. In similar conflicting situations with young women the advisors tend to blame the young women: 'So I thought that there was something wrong with her instead.' If there is a conflict in the interaction with men, however, the advisor can perceive that they are partly to blame. Have they as the representatives of a public authority also in fact contributed to a conflict? When it comes to the unemployed and men, this is something 
employment-agency officials reflect on. He seems to deserve pity, while she can be blamed.

The interviewed advisors emphasize that individual evaluation is always done, but in practice, as our analysis shows, young working-class men gain access to the resources of the employment agency and are given more options. As a result, men have a wider scope for action than working-class women for (re-) entering the labour market. The individual evaluation is, we argue, gender stereotypical. The evaluation is to the advantage of the young working-class men.

\section{Conflicts and sophisticated disciplining}

Conflicts and resistance are more blatant among the young working-class women than among the working-class men. We suggest that there is an informal positional war going on between the young women and the advisors. Out of all the interviewed young people the working-class women express more aggression than anyone else: 'But many times you can feel, what the hell, go there and blow up the shitty place. Good riddance. They don't get that we are ordinary mortals. If you're unemployed, you aren't worth a bloody shit.'

There are examples of these women refusing to submit emotionally to the employment agency's terms, not least in the descriptions of an angry mode of confrontation: 'It's up to them how I should behave. If they are cranky I can be cranky too. If they say that it's so bloody simple - tell you what - let's switch places!'

The demands for reproduction that pressure young women are not particularly visible at the job centre, and this issue is, in other words, routinely understated. The issue is not discussed openly but is implicitly present in both parties. The intersection, as well as the conflict, between the spheres of production and reproduction, is manifested in the actual encounter but remains complex. This might explain why the situation seems especially emotionally tough to handle for the young women. It involves a shortcoming at a structural level - how production and reproduction should be solved in society - but working-class women are left to handle this problem individually. Young working-class women are therefore categorized and disciplined just like 'the others' in a supposedly class- and gender-neutral labour market. But government officials do not do this through the open exercise of authority. The disciplining of working-class women is subtler; it is done through prevailing norms and good advice given with the best of intentions. In the following section we present the experiences of middle-class youths on the basis of valuations of career-oriented jobs and their emotional manifestations.

\section{Few expectations and distanced approach}

Unlike working-class youths, middle-class youths have more modest expectations of the employment agency. They voice cautious scepticism and describe their relations with the advisors in formal terms. The importance of being business-like and keeping a distance are emphasized in contrast to the working-class youths' insistence on personal and equal relations. Taking a distanced approach can be seen in the light of the socioeconomic background linked to career-oriented professions that have informed the lives of middle- 
class youths rather than traditional wage-earning jobs (Jakobsen, 2005; Jakobsen, \& Karlsson 1993).

\section{Shared conceptions and norms}

Middle-class youths' conception of work is in line with the prevailing norms of the employment agency, namely that the future jobs will be based on their unique competence and, unlike working-class youths, they see education as the main instrument of reinforcing their qualifications. The norms are imbued with the importance of obtaining a prominent career position where the young people can decide for themselves how and when the job is to be done. This approach also characterizes their meetings with the job-centre professionals. In comparison with working-class youths, they do not express the same experience of material vulnerability because of being unemployed. Therefore, they are not primarily interested in getting professional help in formulating what, how or when. They will be competitive by solving the situation on their own or with the help of their social network. The basic principle of the employment agency that job-seekers should find their own solutions matches the ideals of the middle- class youth category well.

This pattern is recurring in the interviews with the job-centre advisors of the middle-class youths. The advisors portray these young people as strong and autonomous individuals. There are no accounts of long dialogues full of misunderstandings, as there are in their accounts of conversations with working-class youths. Rather, the interviews with the advisors indicate that unemployed middle-class youths tend to do things in accordance with the advisors' should, that is, acting by the book. Thus, they do not run the risk of being evaluated as 'deficient'.

The middle-class youths' conception of work interacts well with that of the employment agency and they use other means of emotional expression to describe their visits to the job centre. Few or no expectations of the job centre means no disappointment at the outcome: 'I have no expectations of the job centre, so I was quite surprised when I met [officer], a helpful person.'

The middle-class youths are fully aware of the labour market and its terms, but also pay close attention to the advisors' signals: 'I'm eager to keep my unemployment benefit so I can't do what I want. But then I don't know if I would have done things differently? Probably not.' Even if these middle-class young people are also subjected to the continual monitoring of the employment agency, they do not voice discontent. They have a grasp of the labour-market system and see the officials as parts of the system and also master the appropriate conversational tone for interacting with a representative of a public authority. They are expected to be assertive and active. Dialoguing is essential for eliciting information and knowledge, which is also associated with the required intellectual performance of career employment. In comparison with the young working-class people, the middleclass category also takes less time in the form of rumination, or as one of them says: 'You get answers if you contact them', and continues: 'After that I got an appointment with my personal advisor. And I went to talk with her and so she said: "I see, good, keep applying!" And then I got a new appointment.'

It is possible that more help for self-help is welcome when young middle-class people try to maximize their autonomy in accordance with their own view of 
work, that is, as something to 'be responsible for, to develop and to be developed by' (Jakobsen, 1999, p. 179). Also, unemployment is something they should solve on the basis of their own initiatives and this attitude characterizes the interactions with the job centre. According to one advisor, these young people have a clear 'understanding of the services they need when they come here'. They take advantage of the system's potentials and protect their own interests. All is done without any major normative conflicts or emotional tensions.

\section{Discussion}

The aim of the study has been to investigate the interaction between jobcentre advisors and the young unemployed with an emphasis on the young people's experiences and emotional coping, and if the unemployed youths' own living conditions generate different patterns of experiences. Our study shows the interplay between the employment agency as an institutional setting and how gender and class relations interact. In an organizational context the professionals confirm the prevailing labour-market inequality by giving priority to working-class men over working-class women and by confirming the middle-class approach as being consistent with the agency's policy. When the job-centre advisors meet with young people who do not conform to the current labour-market expectations and ideals, they risk participating in an institutional process of exclusion. Unequal social relations are actually confirmed when it is taken for granted that the labour market is class and gender neutral.

Our analysis shows that middle-class youths are best equipped to deal with the agency's advisors. Other research on career-oriented groups on the employment market (Fogde, 2010; Sharone, 2007) supports this finding. It is easier for job-seeking clients to be perceived as unique and independent, that is, employable, if they share the norms of the agency's staff. It is reasonable to assume that working-class youths' high expectations rest on the norms of work in a worker's position. These youngsters have difficulties in handling the agency's conception of work as an interest, a life career. Above all, the young working-class women's wish to combine employment with caregiving is deemed an encumbrance. The working-class young men are allowed to negotiate more freely than young working-class women regarding if, how, and what jobs to apply for. Fogde (2010), who has compared well educated young women's and men's attitudes to career advice, suggests that the existing gender difference depends on women's difficulties in marketing themselves, because this violates conceptions of femininity. Notions of women as being less confident than men are implicitly reproduced. But what exactly is individualized and downgraded? We argue that the values disparaged are those of caregiving and relationships - being there for others, that is, the necessary reproduction of life, which exist beyond the purview of employment market. Working-class youths, and especially the women, display emotions indicating a resistance to and a challenge to the responses they get at the job centre. Oppositional emotions are not necessarily indications of resistance in the form of conscious action intended to challenge power hierarchies (cf. Ambjörnsson 2004). If thus defined, many actions of resistance would be made invisible. In addition, resistance can be counterproductive, leading to further subordination, while those who comply with the system can escape it (Ambjörnsson, 2004). The young working-class women's emotionally stronger opposition emphasizes the gap between their living conditions and opportunities as well as how a normative institution such as the employment 
agency widens this gap. When client-advisor meetings are charged with emotions and value-conflicts, this indicates an institutional process of exclusion of a certain category of the unemployed.

The employment agency's shift towards control measures in the processing of people from unemployment to employment de facto involves increasing demands for individual autonomy, which other studies have also shown (Allen \& Hollingsworth 2013; Yates, Harris, Sabates \& Staff, 2014). In addition, our study reveals that the conceptions of individual autonomy and responsibility in the labour market can be conditional. The advisors act on the basis of stereotypical notions of gender, class, and the young that deviate from an ideal that tends to be challenged. Underlying social conditions are seen as individual shortcomings and the job agency's monitoring further restricts young people with limited options. The advisors impose a change on the workingclass youths that really goes against their material and cultural conditions, namely, their life modes. These young people respond emotionally by defending themselves and reproducing their views from their positions. We can thus regard life modes as strong mechanisms for understanding human everyday life and reality (Jakobsen, 1999). In other words, our data reveal the staff members' process of recreating, confirming, and consolidating inequality, whereby they are participating in a form of institutional exclusion. This process jeopardizes a return to the labour market.

Our results must, however, be treated with caution, not least with respect to their generality. In addition, we cannot be certain if the results exclusively indicate social change in a (Scandinavian) welfare state, namely, Sweden. An objection can be made to the fact that all the interviewed advisors were women. Are young male job-seekers generally better treated at the job centre? Or does this only apply when they meet with women job advisors? When we asked retrospective questions, however, it was apparent that the young women were dissatisfied with female as well as male advisors. Further research could clarify this issue. Yet another issue that needs clarification is whether middle-class youths' affinity with the ideals might mean increased pressure on them to succeed in their career projects.

The young working-class women and men in our study are not absolutely excluded institutionally. However, when exclusion is viewed as a process, unequal social relations are revealed in the organizational context (here, the job centre), which limit and in turn produce opposition. Researchers should study how social processes reproduce and reinforce inequality and over time run the risk of contributing to marginalization and social exclusion. Then strategies for challenging the status quo and promoting change must be developed. How social and gender differences matter is an area of definite and urgent concern for future social policy. 


\section{References}

Allen, K., \& Hollingsworth, S. (2013). Social class, place and urban young people's aspirations for work in the knowledge economy: 'sticky subjects' or 'cosmopolitan creative'? Urban Studies, 50(3), 499-517.

Ambjörnsson, F. (2004). I en klass för sig. Genus, klass och sexualitetet bland gymnasietjejer. [In a class of her own: gender, class, and sexuality among upper-secondary school girls]. Stockholm: Ordfront.

Andersson, M. (2003). Arbetslöshet och arbetsfrihet. [Unemployment and being free from work]. Uppsala: Etnologiska avdelningen.

Ashworth, K., Cebulla, A., Greenberg, D., \& Walker, R, (2004). Meta-Evaluation: Discovering What Works Best in Welfare Provision, Evaluation, 1O(2), 193-216.

Boolsen, M.W. (2007). Kvalitativa intervjuer [Qualitative Interviews]. Malmö: Gleerups.

Calmfors, L., Forslund, A., \& Hemström, M. (2002). Does active labour market policy work? Institute for international Economic Studies, Seminar Paper No 700. Stockholm: Stockholm University.

Dahlgren, L., \& Starrin, B. (2004). Emotioner, vardagsliv och samhälle [Emotions, Everyday Life, and Society]. Malmö: Liber.

Fogde, M. (2010). Governing through career coaching: negotations of self-marketing. Organization, 18(1), 65-82.

Garsten, C., \& Jacobsson K. (Eds.). (2004). Learning to be employable: New Agendas on Work, Responsibility and Learning in a Globalising World. Basingstoke: Palgrave.

Hagquist, C. (2000). Socioeconomic differences in smoking behavior among adolescents. Childhood, 7(4), 467-478.

Hasenfeld, Y. (2000). Organizational forms as moral practices: The case of welfare departments. Social Service Review, 74(3), 329-351.

Heikkilä, M. (1999). Linking Welfare and Work. Dublin: European Foundation for the improvement of Living and Working Conditions.

Hochschild, A.R. (1990). Ideology and emotion management: A perspective and path for future research. In T.D. Kemper (Ed.), Research agendas in the sociology of emotions (pp. 117-144). New York: State University of New York Press.

Hydén, L.C. (1996). Applying for money. The encounter between social workers and clients: A question of morality. British Journal of Social Work, 26(6), 843-860.

Højrup, T. (1989). Det glemte folk [The forgotten people]. Köpenhamn: Statens Byggeforskningsinstitut.

Jakobsen, L. (2005). Life Modes and Gender in the Swedish Public-Health Sector. In L. Gonäs, \& J. Ch. Karlsson (Eds), Gender Segregation, Divisions of Work in PostIndustrial Welfare States (pp. 111-126). London: Ashgate.

Jakobsen, L. (1999). Livsform, kön och risk. En utveckling och tillämpning av realistisk livsformsanalys [Life Mode, Gender, and Risk: A development and application of a Realist Life Modes Analysis]. Lund: Arkiv förlag.

Jakobsen, L., \& Karlsson, J. Ch. (1993). Arbete och kärlek - en utveckling av livsformsanalys. [Work and Love: A development of a Life Modes Analysis]. Lund: Arkiv förlag. 
Jónaisdóttir, A.G. (1994). Why Women Are Oppressed. Philadelphia: Temple University Press.

Kennerberg, L. (2007). Hur förändras kvinnors och mäns arbetssituation när de får barn? [How do women's and men's work situations change when they get children?]. Rapport 2007: 9. Uppsala: IFAU.

Kronauer, M. (1998). 'Social exclusion' and 'underclass' - new concepts for the analysis of poverty. In H.J. Andress (Ed.), Empirical poverty research in a comparative perspective (pp. 51-75). Aldershot: Ashgate.

Kugelberg, C. (2004). Jämställdhetsideal och könsdiskriminering [The ideals of equality and gender discrimination]. Arbetsmarknad \& Arbetsliv. 10(2), 95-116.

Kvale, S., \& Brinkmann, S. (2009). Den kvalitativa forskningsintervjun [The Qualitative Research Interview]. Lund: Studentlitteratur.

Layder, D. (1998). Sociological Practice: Linking Theory and Social Research. London: Sage.

Lipsky, M. (1980). Street-level bureaucracy: Dilemmas of the individual in public services. New York: Russell Sage.

Lodenius, A.L. (2005). En arbetslös man är värd två arbetslösa kvinnor [One unemployed man is worth two unemployed women]. Ordfront Magasin, no 5.

McArthur, M., Thomson, L., \& Winkworth, G. (2013). Jumping through hoops - the cost of compliance on sole parents. Child and Family Social Work, 18(2), 159-167.

Persson Thunkvist, D. (2003). Samtal för arbete. Kommunikativa erfarenheter $i$ kommunala ungdomsprojekt [Talk for work: Communicative activities in municipal youth projects]. Linköping: Tema Kommunikation.

Rodgers, G., Gore, C., \& Figueiredo, J.B. (1995). Social exclusion: Rhetoric, Reality Responses. Geneva: International Institute for Labour Studies

Romppainen, K., Jähi, R., Saloniemi, A., \& Virtanen, P. (2010). Encounters with unemployment in occupational health care. Social Science \& Medicine, 70(4), 605-608.

Salomonsson, K. (2005). Flexible, Adaptable, Employable: Ethics for a new labour Market. In O. Löfgren (Ed.), Magic, Culture and the New Economy (pp. 117129). Oxford: Berg Publishers.

Sharone, O. (2007). Constructing Unemployed Job Seekers as Professional Workers: The Depoliticizing Work-Game of Job Searching. Qualitative Sociology, 30(4), 403-416.

Silverman, D (2006). Interpreting qualitative data. Third edition. London: Sage.

Skeggs, B. (1997). Formations of Class and Gender. Becoming respectable. London: Sage Publications

Skogens, L. (2011). Labour market status, requirements and social support - single male clients with problematic alcohol consumption. European Journal of Social Work, 14(4), 513-523.

Svensson, T., Karlsson, A., Alexandersson, K., \& Nordqvist C. (2003). Shame Inducing Encounters. Journal of Occupational Rehabilitation, 13(3), $183-195$.

Tilly, C. (1998). Durable Inequality. Los Angeles: University of California Press.

Walby, S., Armstrong, J., \& Strid, S. (2012). Intersectionality: Multiple Inequalities in Social Theory. Sociology, 46(2), 224-240. 
Walter, L. (2011). Arbetsförmedlingens dubbla funktion att stödja och kontrollera [The employment agency's dual function to support and control]. In C. Garsten, R. Lindvert, \& R. Thedvall (Eds.), Arbetets marknad - Arbetsmarknadens nya organisering [The employment market: the labour market's new organization]. Malmö: Liber.

Yates, S., Harris, A., Sabates, R., \& Staff, J. (2011). Early occupational aspirations and fractured transitions: a study of entry into 'NEET' status in the UK. Journal of Social Policy, 40(03), 513-534. 